\title{
A VALIDATED DENSITOMETRIC METHOD FOR ANALYSIS OF TELMISARTAN AND ATORVASTATIN CALCIUM IN FIXED DOSE COMBINATION
}

\author{
U. P. PATIL, S. V. GANDHI*, M. R. SENGAR, V. S. RAJMANE \\ Department of Pharmaceutical Analysis, AISSMS College of Pharmacy, Kennedy Road, Pune - 411 001, MH, India \\ Santosh V. Gandhi \\ AISSMS College of Pharmacy, Kennedy road, Near R.T.O., Pune. 411 001. Maharashtra, India. \\ (Received: June 1, 2009 - Accepted: July 28, 2009)
}

\begin{abstract}
A simple, specific, accurate and precise high-performance thin-layer chromatographic method for analysis of Telmisartan and Atorvastatin calcium in fixed dose combination has been developed. The method uses aluminium plates coated with silica gel $60 \mathrm{~F}_{254}$ as stationary phase and toluene: methanol (7: 3 , v/v) as mobile phase. Densitometric evaluation of the separated bands was performed at $280 \mathrm{~nm}$. The two drugs were satisfactorily resolved with Rf values $0.50 \pm 0.01$ and $0.29 \pm 0.00$ for Telmisartan and Atorvastatin calcium, respectively. The respective calibration plots were found to be linear over the range 200-1000 and 200-700 ng/band for Telmisartan and Atorvastatin calcium, respectively. This method has been successfully validated and applied for the analysis of drugs in pharmaceutical formulation.
\end{abstract}

Keywords: High-performance thin-layer chromatography, telmisartan, atorvastatin calcium

\section{INTRODUCTION}

Atorvastatin calcium (ATV), ( $\beta R, d R)-2-(4-f l u o r o p h e n y l)-\beta, d-d i h y d r o x y-$ 5-(1-methylethyl)-3-phenyl-4-[(phenylamino)carbonyl]-1H-pyrrole-1heptanoic acid, calcium salt, is a synthetic cholesterol-lowering agent ${ }^{1}$ and is official in Indian Pharmacopoeia. Official assay method is by HPLC ${ }^{2}$. Literature survey reveals spectroscopic method for determination of ATV in combination with amlodipine besylate ${ }^{3}$. HPTLC methods have been reported for estimation of ATV in biological sample as a single drug $^{4}$ and in pharmaceutical sample in combination with ezetimibe ${ }^{5}$. Several HPLC methods are reported for determination of ATV in bulk drugs and tablets ${ }^{6-7}$. Stability indicating HPLC methods are also reported for estimation of ATV in combination with other drugs $^{8-10}$.

Telmisartan (TEL) is described chemically as $4[(1,4$-dimethyl-2propyl (2, 6-bi-1H-benzimidazol]-1-yl) methyl] [1, 1-biphenyl]-2-carboxylic acid $^{11}$. TEL is useful in the treatment of mild to moderate hypertension ${ }^{12}$. Few spectrophotometric methods have been reported for estimation of TEL in pharmaceutical dosage form as a single drug or in combination with other drugs ${ }^{12-13}$. HPTLC methods are also reported for the determination of TEL in formulation ${ }^{14-15}$.

Extensive literature survey reveals that no HPTLC method is available for determination of Atorvastatin Calcium and Telmisartan in combined tablet dosage form. Aim of present work was to develop a simple, precise, accurate and economical HPTLC method for determination of binary drug formulation.

\section{EXPERIMENTAL}

\section{Reagents and Chemicals}

Methanol, toluene (all AR grade) were obtained from Thomas Baker (chemicals) Pvt. Ltd. (Mumbai, India). Standard bulk drug samples of TEL (99.65\% pure) and ATV (99.83\% pure) were provided as gift sample by Glenmark Pharmaceuticals Ltd. (Nasik, India) and Hetero Drugs Ltd. (HP, India), respectively. The pharmaceutical dosage form used in this study was Tele Act ST 20 film coated tablets (Hetero Drugs Ltd. HP, India) labeled to contain telmisartan $20 \mathrm{mg}$ and atorvastatin calcium IP equivalent to atorvastatin $10 \mathrm{mg}$ per tablet.

Instrumentation and Chromatographic Conditions

Chromatography was performed on $20 \mathrm{~cm} \times 10 \mathrm{~cm}$ aluminum plates precoated with silica gel $60 \mathrm{~F}_{254}$ (E. Merck, Darmstadt, Germany). Before use the plates were prewashed with methanol and activated at $110^{\circ} \mathrm{C}$ for $5 \mathrm{~min}$ Samples were applied to the plates as bands $6 \mathrm{~mm}$ wide and $6.8 \mathrm{~mm}$ apart by means of a Camag (Switzerland) Linomat 5 sample applicator equipped with a $100 \mu \mathrm{L}$ syringe (Hamilton, Bonaduz, Switzerland). Linear ascending development was performed in a $20 \mathrm{~cm} \times 10 \mathrm{~cm}$ twin trough glass chamber (Camag) using toluene: methanol $(7: 3, v / v)$ as mobile phase after saturation of the chamber with mobile phase vapor for $30 \mathrm{~min}$. The development distance was $9 \mathrm{~cm}$ and the development time approximately $30 \mathrm{~min}$. After chromatography the plates were dried in a current of air by use of a hair dryer. Densitometric scanning was performed with a Camag TLC Scanner 3 at $280 \mathrm{~nm}$ for all measurements. The scanner was operated by Wincats software Version 1.4.2. The source of radiation was a deuterium lamp emitting a continuous UV spectrum between 200 and $400 \mathrm{~nm}$. The slit dimensions were $5 \mathrm{~mm} \mathrm{X} 0.45 \mathrm{~mm}$ and the scanning speed was $20 \mathrm{~mm} / \mathrm{s}$.

\section{Preparation of Standard Stock Solutions}

A standard stock solution of TEL and ATV were prepared by dissolving 10 $\mathrm{mg}$ drug in $10 \mathrm{~mL}$ methanol to furnish a concentration of $1 \mathrm{mg} / \mathrm{mL}$. From this stock solution $1 \mathrm{~mL}$ was further diluted to $10 \mathrm{~mL}$ with methanol to get working standard solution of $100 \mu \mathrm{g} / \mathrm{mL}$ of each drug.

\section{VALIDATION}

The proposed method was optimized and validated in accordance with International Conference on Harmonization (ICH) guidelines ${ }^{16}$.

Linearity

The working standard solutions of TEL $(100 \mu \mathrm{g} / \mathrm{mL})$ and ATV $(100 \mu \mathrm{g} /$ $\mathrm{mL}$ ) were applied by overspotting on a TLC plate, in the range $2-10 \mu \mathrm{L}$, by use of the Linomat 5 sample applicator and $100 \mu \mathrm{L}$ syringe. The plate was developed and scanned under the conditions described above. Each amount was analyzed five times and peak areas were recorded. Calibration plots of peak area against respective amount were established separately for TEL and ATV.

\section{LOD and LOQ}

LOD and LOQ were calculated, in accordance with ICH guidelines, as 3.3 $\sigma / \mathrm{S}$ and $10 \sigma / \mathrm{S}$, respectively, where $\sigma$ is the standard deviation of the response (y-intercept) and $\mathrm{S}$ is the slope of the calibration plot.

Precision

To study intra-day variation, solutions of TEL and ATV were prepared and applied to the TLC plates in linearity range ( 3 concentrations $\times 3$ replicates). All the solutions were analyzed on the same day to record any intra day variation in the results. To study inter-day variation, analysis of three standard solutions in triplicate in linearity range was performed on different days.

\section{Robustness}

The effect of small, deliberate variation of the analytical conditions on the peak areas of the drugs was examined. Time from application to development $(0,10,20,30 \mathrm{~min})$, from development to scanning $(0,30,60,90 \mathrm{~min})$, volume of mobile phase $( \pm 10 \%)$ and development distance $( \pm 10 \%)$ were varied. One factor at a time was changed to study the effect.

Accuracy

To check the accuracy of the method, recovery studies were carried out by addition of standard drug solution to pre-analyzed sample solution at three 
different levels 80,100 , and $\quad 120 \%$ to pre-analyzed sample solution. Three replicates were analyzed for each level.

\section{RESULTS AND DISCUSSION}

\section{Selection of Detection Wavelength}

After chromatographic development, bands were scanned over the range 200-400 nm (spectrum scan speed $100 \mathrm{~nm} / \mathrm{s}$ ) and the spectra were overlain. At $280 \mathrm{~nm}$, TEL as well as ATV has considerable absorbance so this wavelength was selected as detection wavelength (Fig. 1).

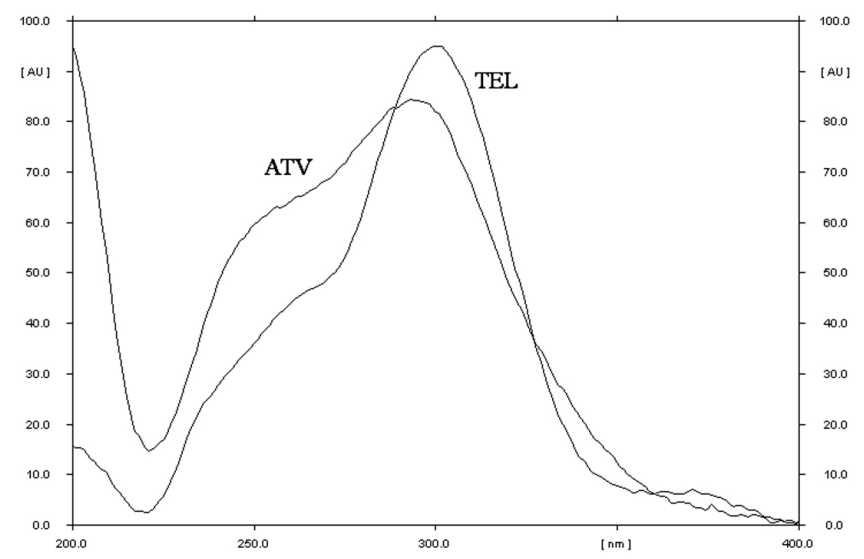

Fig. 1: Overlain spectrum of ATV and TEL recorded in-situ on plate from $200-400 \mathrm{~nm}$.

\section{Method Development}

Different mobile phases containing toluene, methanol, chloroform, ethyl acetate, and triethylamine in different proportions were examined (results not shown). Toluene: methanol $(7: 3, \mathrm{v} / \mathrm{v})$ was finally selected because it resulted in acceptable resolution of the bands with Rf values of $0.50 \pm 0.01$ for TEL and $0.29 \pm 0.00$ for ATV. The densitogram obtained from an overspotting solution of TEL and ATV is shown in Fig. 2.

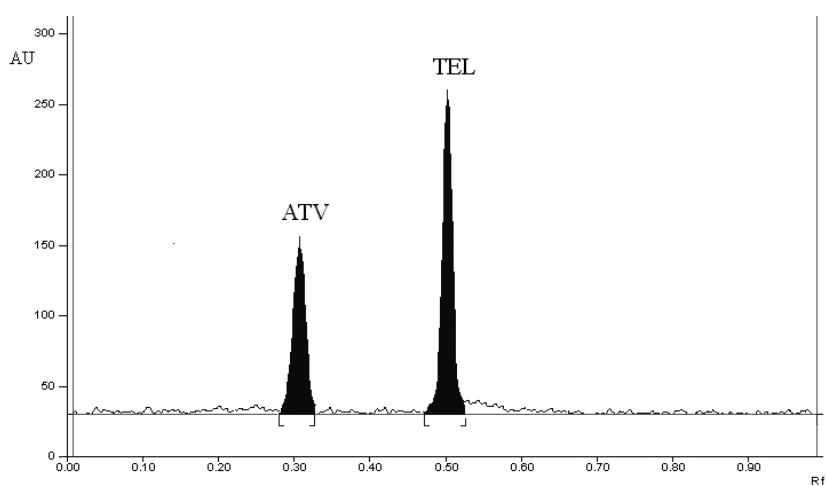

Fig. 2: Densitogram obtained from a mixed standard solution of ATV (300 $\mathrm{ng} / \mathrm{band}$; Rf $0.29 \pm 0.00)$ and TEL (300 ng/band; Rf $0.50 \pm 0.01)$ at $280 \mathrm{~nm}$.

\section{Analysis of Tablet Formulation}

Twenty tablets were weighed accurately and finely powdered. A quantity of powder equivalent to $10 \mathrm{mg}$ ATV was weighed and transferred to a $10 \mathrm{~mL}$ volumetric flask containing approximately $5 \mathrm{~mL}$ methanol. The mixture was ultrasonicated for $5 \mathrm{~min}$ and diluted to volume with methanol. The solution was filtered using Whatman no. 41 paper. From stock solution $1 \mathrm{~mL}$ was taken and diluted to $10 \mathrm{~mL}$ with methanol. $3 \mu \mathrm{L}$ of this stock solution was applied to a TLC plate. After chromatographic development the peak areas of the bands were measured at $280 \mathrm{~nm}$ and the amount of each drug in sample was determined from the respective calibration plots. The analytical procedure was repeated six times for the homogenous powdered sample. The results of commercial formulation analysis are shown in Table 1.
Table 1: Results of commercial formulation analysis.

\begin{tabular}{|ccc|}
\hline $\begin{array}{c}\text { Label Claim } \\
(\mathbf{m g} / \mathbf{T A B})\end{array}$ & $\begin{array}{c}\text { \% Lable Claim Estimated } \\
(\text { Mean } \pm \text { S.D) }(\mathbf{n}=\mathbf{6})\end{array}$ & \% R. S. D. \\
\hline TEL-20 & $99.76 \pm 1.22$ & 1.22 \\
ATV-10 & $99.59 \pm 1.28$ & 1.28 \\
\hline
\end{tabular}

The calibration plots were found to be linear over the ranges $200-1000$ and $200-700 \mathrm{ng} / \mathrm{band}$ for TEL and ATV, respectively. Results of validation parameters are shown in Table 2.

Table 2: Validation Parameters.

\begin{tabular}{|ccc|}
\hline PARAMETERS & ATV & TEL \\
\hline $\begin{array}{c}\text { Linearity range (ng/ } \\
\text { band) }\end{array}$ & $200-700$ & $200-1000$ \\
\hline $\begin{array}{c}\text { Regression equation } \\
\text { ( }\end{array}$ & $\mathrm{y}=5.5354 \mathrm{x}-254.61$ & $\mathrm{y}=4.6025 \mathrm{x}+1672.1$ \\
\hline $\mathrm{r}^{2 *}$ & 0.9994 & 0.9943 \\
\hline $\begin{array}{c}\text { Precision (\% RSD) } \\
\text { Intraday } \\
\text { Interday }\end{array}$ & 0.87 & 0.56 \\
\hline $\begin{array}{c}\text { LOD (ng/band) } \\
1.21\end{array}$ & 43.54 \\
\hline LOQ (ng/band) & 143.68 & 50.14 \\
\hline
\end{tabular}

*average of five determinations

The results of recovery studies are shown in Table 3.

Table 3: Recovery studies of TEL and ATV.

\begin{tabular}{|c|c|c|c|c|}
\hline \multirow{4}{*}{ TEL } & $\begin{array}{c}\text { Amount } \\
\text { Taken } \\
\text { (ng / } \\
\text { band) }\end{array}$ & $\begin{array}{c}\text { Amount } \\
\text { added } \\
\text { (ng / } \\
\text { band) }\end{array}$ & $\begin{array}{l}\text { Total Amount } \\
\text { found } \\
\text { (ng / band) }\end{array}$ & $\begin{array}{c}\text { \% Recovery } \\
(\text { Mean } \pm \text { S.D) }\end{array}$ \\
\hline & 300 & 240 & 541.78 & $100.33 \pm 0.79$ \\
\hline & 300 & 300 & 597.96 & $99.66 \pm 1.02$ \\
\hline & 300 & 360 & 656.63 & $99.49 \pm 0.69$ \\
\hline \multirow{3}{*}{ ATV } & 300 & 240 & 537.62 & $99.56 \pm 1.11$ \\
\hline & 300 & 300 & 603.00 & $100.5 \pm 0.82$ \\
\hline & 300 & 360 & 652.87 & $98.92 \pm 0.59$ \\
\hline
\end{tabular}

\section{CONCLUSION}

The validated HPTLC method employed here proved to be simple, rapid, accurate, precise, sensitive and robust and can thus be used for routine analysis of TEL and ATV in a combined tablet dosage form.

\section{ACKNOWLEDGMENTS}

The authors wish to express their gratitude to Glenmark Pharmaceuticals Ltd., Nasik, India) for the sample of pure telmisartan, and to Hetero Drugs Ltd. (HP, India) for the sample of pure atorvastatin calcium. The authors are also thankful to Dr. K. G. Bothara, Principal, AISSMS College of Pharmacy for providing necessary facilities and his constant support. 


\section{REFERENCES}

1. The Merck index, $13^{\text {th }}$ Ed., Merck and Co. Inc, White House Station. N J (1997) pp.868.

2. Indian Pharmacopoeia Vol II, New Delhi: The controller of Publication: (2007) pp.749.

3. R. Sahu, V. B. Patel, Indian J. Pharm Sci., 69, 110, (2007).

4. A. Jamshidi, A. R. Nateghi, Chromatographia, 65, 763, (2007).

5. B. G. Chaudhari, N. M. Patel, P. B. Shah, K .P. Modi, Indian J. Pharm. Sci., 68, 793, (2006).

6. X. S. Miao, C. D. Metcalfe, J. Chromatogr. A, 998, 133, (2003).

7. S. Ertürk, E. S. Akta, L. Ersoy, S. Fiçıciolu, J. Pharm. Biomed. Anal., 33, 1017, (2003).

8. A. Mohammadi, N. Rezanour, M. Ansari Dogaheh, F. Ghorbani Bidkorbeh, M. Hashem, R. B. Walker, J. Chromatogr,. B, 846, 215, (2007).

9. B. G. Chaudhari, N. M Patel, P. B. Shah, Chem. Pharm. Bull., 55, 241, (2007).
10. B. G. Chaudhari, N. M. Patel, P. B. Shah, L. J. Patel, V. P. Patel, J. Am. Oil Chem. Soc., 90, 1539, (2007).

11. The Merck Index, $13^{\text {th }}$ Ed., Merck and Co. Inc, White House Station. N J (2001) pp.1628

12. M. S. Palled, M. Chatter, P. M. N. Rajesh, A. R. Bhat, Indian J. Pharm. Sci., 68, 685, (2006).

13. S. Bankey, G. G. Tapadiya, S. S. Saboo, S. Bindaiya, D. Jain, S. S. Khadbadi, International Journal of Chem Tech Research 1,183 (2009).

14. N. J. Shah, B. N. Suhagia, R. R. Shah, P. B. Shah, Indian J. Pharm. Sci,. 69, 202, (2007).

15. C. Prabhu, G. S. Subramanian, A. Karthik, S. Kini, M. S. Rajan, N. Udupa, J. Planar Chromatogr., 20, 477, (2007).

16. International Conference on Harmonization of Technical Requirements for Registration of Pharmaceuticals for Human Use, ICH Harmonised Tripartite Guideline, Validation of Analytical Procedures: Text and Methodology Q2(R1), Complementary Guideline on Methodology dated 06 November 1996, incorporated in November 2005, London. 